\title{
Synthesis and Characterization of New Mono- $N$-functionalized Tetraaza Macrocyclic Nickel(II) and Copper(II) Complexes
}

\author{
Hyunja Kim and Shin-Geol Kang* \\ Department of Chemistry, Daegu University, Gyeongsan 712-714, Korea.*E-mail: sgkang@daegu.ac.kr \\ Received May 20, 2011, Accepted June 14, 2011
}

\begin{abstract}
The reaction of bromoacetonitrile with 3,14-dimethyl-2,6,13,17-tetraazatetracyclo[16.4.1 $\left.1^{2.6} \cdot 0^{1.18} \cdot 0^{7.12}\right]$ tricosane $\left(\mathrm{L}^{10}\right)$ containing a $\mathrm{N}-\mathrm{CH}_{2}-\mathrm{N}$ linkage produces 17-cyanomethyl-3,14-dimethyl-2,6,13,17-tetraazatetracyclo$\left[16.4 .1^{2.6} \cdot 0^{1.18} \cdot 0^{7.12}\right]$ tricosane $\left(\mathrm{L}^{11}\right)$. The mono- $N$-functionalized macrocyclic complexes $\left[\mathrm{ML}^{2}\right]^{2+}(\mathrm{M}=\mathrm{Ni}(\mathrm{II})$ or $\mathrm{Cu}(\mathrm{II}) ; \mathrm{L}^{2}=2$-cyanomethyl-5,16-dimethyl-2,6,13,17-tetraazatricyclo[16.4.0.0 $\left.0^{7.12}\right]$ docosane) can be prepared by the reaction of $\mathrm{L}^{11}$ with nickel(II) or copper(II) ion in acetonitrile. The $N-\mathrm{CH}_{2} \mathrm{CN}$ group attached to $\left[\mathrm{ML}^{2}\right]^{2+}$ readily reacts with water or methanol to yield the corresponding complexes of $\mathrm{HL}^{3}$ bearing one $N-\mathrm{CH}_{2} \mathrm{CONH}_{2}$ pendant arm or $\mathrm{L}^{4}$ bearing one $\mathrm{N}-\mathrm{CH}_{2} \mathrm{C}(=\mathrm{NH}) \mathrm{OCH}_{3}$ group. The $\mathrm{N}-\mathrm{CH}_{2} \mathrm{CONH}_{2}$ or $\mathrm{N}-\mathrm{CH}_{2} \mathrm{C}(=\mathrm{NH}) \mathrm{OCH}_{3}$ group of each complex is coordinated to the central metal ion. Both $\left[\mathrm{NiL}^{4}\left(\mathrm{H}_{2} \mathrm{O}\right)\right]^{2+}$ and $\left[\mathrm{CuL}^{4}\right]^{2+}$ are quite stable in acidic aqueous solutions, but undergo hydrolysis to yield $\left[\mathrm{Ni}\left(\mathrm{HL}^{3}\right)\left(\mathrm{H}_{2} \mathrm{O}\right)\right]^{2+}$ or $\left[\mathrm{Cu}\left(\mathrm{HL}^{3}\right)\right]^{2+}$ in basic aqueous solutions. In contrast to $\left[\mathrm{Cu}\left(\mathrm{HL}^{3}\right)\right]^{2+},\left[\mathrm{Ni}\left(\mathrm{HL}^{3}\right)\left(\mathrm{H}_{2} \mathrm{O}\right)\right]^{2+}$ is readily deprotonated to form $\left[\mathrm{NiL}^{3}\left(\mathrm{H}_{2} \mathrm{O}\right)\right]^{+}\left(\mathrm{L}^{3}=\mathrm{a}\right.$ deprotonated form of $\mathrm{HL}^{3}$ ) in basic aqueous solutions.
\end{abstract}

Key Words : Macrocyclic complexes, Mono- $N$-functionalized macrocycle, Functional pendant arm, Hydrolysis, Methanolysis

\section{Introduction}

Polyaza macrocyclic compounds bearing functional pendant $\operatorname{arm}(\mathrm{s})$ have attracted a great attention because of their interesting chemical properties and potential applications in various fields. ${ }^{1-24}$ The introduction of functional pendant arm(s) into polyaza macrocycles often leads to significant changes in chemical properties of the ligands. Chemical properties and coordination behaviors of such compounds are also influenced by the number of the functional group. ${ }^{11-15}$ For example, two $\mathrm{N}-\mathrm{CH}_{2} \mathrm{CH}_{2} \mathrm{OH}$ groups of $\left[\mathrm{NiL}^{8}\right]^{2+}$ are coordinated to the central metal ion, whereas the functional group of $\left[\mathrm{Ni}\left(\mathrm{HL}^{9}\right)\right]^{2+}$ is not involved in coordination in the solid state. ${ }^{10,15}$ The $\mathrm{N}-\mathrm{CH}_{2} \mathrm{CH}_{2} \mathrm{OH}$ groups of $\left[\mathrm{NiL}^{8}\right]^{2+}$ are known to be quite resistant to deprotonation in basic aqueous solutions. ${ }^{10}$ On the other hand, $\left[\mathrm{Ni}\left(\mathrm{HL}^{9}\right)\right]^{2+}$ is readily deprotonated to yield $\left[\mathrm{NiL}^{9}\left(\mathrm{H}_{2} \mathrm{O}\right)\right]^{2+}\left(\mathrm{L}^{9}=\right.$ a deprotonated form of $\left.\mathrm{HL}^{9}\right){ }^{15}$ Although a number of functionalized tetraaza macrocycles and their metal complexes have been prepared and investigated to date, those bearing only one functional pendant arm are relatively rare. ${ }^{11-15}$ This may be attributed in part to the fact that selective substitution to one of the four secondary amino groups in a 14-membered tetraaza macrocycle often requires several steps and/or is difficult. Therefore, we have been interested in the regioselective $N$-functionalization of 14-membered tetraaza macrocycles.

Polyaza macrocyclic compounds bearing $N-\left(\mathrm{CH}_{2}\right)_{\mathrm{n}} \mathrm{CN}$ (n $=1$ or 2) pendant arms are useful precursors for the preparation of various types of functionalized macrocyclic complexes. ${ }^{16-23}$ For instance, $\left[\mathrm{ML}^{5}\right]^{2+}(\mathrm{M}=\mathrm{Ni}(\mathrm{II})$ or $\mathrm{Cu}(\mathrm{II}))$ bearing two $\mathrm{N}-\mathrm{CH}_{2} \mathrm{CN}$ groups reacts with water or methanol under relatively mild conditions to give $\left[\mathrm{ML}^{6}\right]^{2+}$ bearing two $\mathrm{N}-\mathrm{CH}_{2} \mathrm{CONH}_{2}$ (amide) groups or $\left[\mathrm{ML}^{7}\right]^{2+}$ bearing two $N$ $\mathrm{CH}_{2} \mathrm{C}(=\mathrm{NH}) \mathrm{OCH}_{3}$ (imidate ester) pendant arms. ${ }^{17,23}$ It has been revealed that the reactivity of the $\mathrm{N}-\mathrm{CH}_{2} \mathrm{CN}$ group attached to a macrocyclic complex is strongly influenced by the nature of the central metal ion.

In this work, we prepared $\left[\mathrm{ML}^{2}\right]^{2+}$ bearing only one $N$ $\mathrm{CH}_{2} \mathrm{CN}$ pendant arm. The complexes of $\mathrm{HL}^{3}$ and $\mathrm{L}^{4}$ bearing one $\mathrm{N}-\mathrm{CH}_{2} \mathrm{CONH}_{2}$ or one $\mathrm{N}-\mathrm{CH}_{2} \mathrm{C}(=\mathrm{NH}) \mathrm{OCH}_{3}$ pendant arm were also prepared by the reaction of $\left[\mathrm{ML}^{2}\right]^{2+}$ with water or methanol. Interestingly, the $\mathrm{N}-\mathrm{CH}_{2} \mathrm{CONH}_{2}$ group attached to $\left[\mathrm{Ni}\left(\mathrm{HL}^{3}\right)\right]^{2+}$ was found to be much more acidic than that of $\left[\mathrm{Cu}\left(\mathrm{HL}^{3}\right)\right]^{2+}$ or $\left[\mathrm{NiL}^{6}\right]^{2+}$. Herein we report an efficient synthesis and chemical properties of the nickel(II) and copper(II) complexes of $\mathrm{L}^{2}-\mathrm{L}^{4}$.

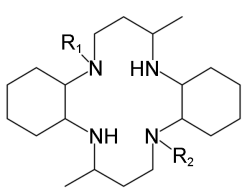
$\mathrm{L}^{1}: \mathrm{R}_{1}=\mathrm{R}_{2}=\mathrm{H}$
$\mathrm{L}^{2}: \mathrm{R}_{1}=\mathrm{CH}_{2} \mathrm{CN} ; \mathrm{R}_{2}=\mathrm{H}$
$\mathrm{HL}^{3}: \mathrm{R}_{1}=\mathrm{CH}_{2} \mathrm{CONH}_{2} ; \mathrm{R}_{2}=\mathrm{H} \quad \mathrm{L}^{4}: \mathrm{R}_{1}=\mathrm{CH}_{2} \mathrm{C}(=\mathrm{NH}) \mathrm{OCH}_{3} ; \mathrm{R}_{2}=\mathrm{H}$
$\mathrm{L}^{5}: \mathrm{R}_{1}=\mathrm{R}_{2}=\mathrm{CH}_{2} \mathrm{CN} \quad \mathrm{L}^{6}: \mathrm{R}_{1}=\mathrm{R}_{2}=\mathrm{CH}_{2} \mathrm{CONH}_{2}$
$\mathrm{L}^{7}: \mathrm{R}_{1}=\mathrm{R}_{2}=\mathrm{CH}_{2} \mathrm{C}(=\mathrm{NH}) \mathrm{OCH}_{3} \quad \mathrm{~L}^{8}: \mathrm{R}_{1}=\mathrm{R}_{2}=\mathrm{CH}_{2} \mathrm{CH}_{2} \mathrm{OH}$
$\mathrm{HL}^{9}: \mathrm{R}_{1}=\mathrm{CH}_{2} \mathrm{CH}_{2} \mathrm{OH} ; \mathrm{R}_{2}=\mathrm{H}$

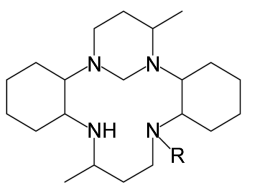

$\mathrm{L}^{10}: \mathrm{R}=\mathrm{H} \quad \mathrm{L}^{11}: \mathrm{R}_{1}=\mathrm{CH}_{2} \mathrm{CN}$ 


\section{Experimental}

Measurements. Electronic absorption spectra were recorded with an Analytikjena Specord 200 UV-vis spectrophotometer, infrared spectra with a Genesis II FT-IR spectrophotometer, NMR spectra with a Varian Mercury 300 FT NMR spectrometer, and conductance measurements with a Metrohm Herisau Conductometer E518. GC-mass spectra were measured with a Shimadzu GCMSD-QP5050 spectrometer. FAB mass spectra were performed at the Korea Basic Science Institute, Daegu, Korea. Elemental analyses were performed at the Research Center for Instrumental Analysis, Daegu University, Gyeongsan, Korea. Magnetic moments were calculated from magnetic susceptibility data obtained at $293 \mathrm{~K}$ using a Johnson Matthey MK-1 magnetic susceptibility balance.

Safety Note. Perchlorate salts of metal complexes with organic ligands are often explosive and should be handled with great caution.

Preparation of 17-Cyanomethyl-3,14-dimethyl-2,6,13, 17-tetraazatetracyclo $\left[16.4 .1^{2.6} \cdot 0^{1.18} \cdot 0^{7.12}\right]$ tricosane $\left(L^{11}\right)$ and $\left[\mathrm{NiL}^{2}\right]\left(\mathrm{ClO}_{4}\right)_{2} \cdot \mathrm{H}_{2} \mathrm{O}\left(\mathrm{L}^{2}=\right.$ 2-cyanomethyl-5,16-dimethyl2,6,13,17-tetraazatricyclo[16.4.0.0 $\left.{ }^{7.12}\right]$ docosane). The macropolycycle $\mathrm{L}^{10}$ was prepared by the reaction of $\mathrm{L}^{1}$ with formaldehyde. ${ }^{24}$ A chloroform solution $(20 \mathrm{~mL})$ of $\mathrm{L}^{10}$ $(2.0 \mathrm{~g}, 5.7 \mathrm{mmol})$ and bromoacetonitrile $(0.5 \mathrm{~mL}, 6.9 \mathrm{mmol})$ was stirred for $24 \mathrm{~h}$ at room temperature and then refluxed for $30 \mathrm{~min}$. The resulting solution was evaporated on a rotary evaporator to dryness. After dissolving the residue in acetonitrile $(20 \mathrm{~mL}), 1.0 \mathrm{M} \mathrm{NaOH}$ aqueous solution $(20 \mathrm{~mL})$ was added to the solution. The mixture was evaporated at room temperature to precipitate a white solid. The product was collected by filtration and washed with methanol. It was recrystallized by evaporating a chloroform-methanol (1:1) solution $(30 \mathrm{~mL})$ of the product. Yield: $50-60 \%$. GC-mass $(\mathrm{m} / \mathrm{z})$ : 386 for $\mathrm{L}^{11}$. Anal. Found: C, 68.97; H, 11.25; N, 18.93. Calc. for $\mathrm{C}_{23} \mathrm{H}_{41} \mathrm{~N}_{5}\left(\mathrm{~L}^{11}\right)$ : $\mathrm{C}, 71.27 ; \mathrm{H}, 10.66 ; \mathrm{N}$, 18.07\%. IR $\left(\mathrm{cm}^{-1}\right): 3320\left(v_{\mathrm{N}-\mathrm{H}}\right)$ and $2230\left(v_{\mathrm{C} \equiv \mathrm{N}}\right)$. Although mass spectrum of the product shows a main peak corresponding to $\mathrm{L}^{11}$, it also contains a small amount of uncharacterized by-product(s). Unfortunately, the isolation of $\mathrm{L}^{11}$ as its pure form was very difficult, and the crude product was used for the preparation of $\left[\mathrm{NiL}^{2}\right]\left(\mathrm{ClO}_{4}\right)_{2} \cdot \mathrm{H}_{2} \mathrm{O}$ and $\left[\mathrm{CuL}^{2}\right]-$ $\left(\mathrm{ClO}_{4}\right)_{2} \cdot \mathrm{H}_{2} \mathrm{O}$.

An acetonitrile suspension $(25 \mathrm{~mL})$ of $\mathrm{L}^{11}$ and $\mathrm{Ni}(\mathrm{OAc})_{2} \cdot 4 \mathrm{H}_{2} \mathrm{O}$ $(2.5 \mathrm{~g}, 10 \mathrm{mmol})$ was refluxed for $1 \mathrm{~h}$ and then cooled to room temperature. After the addition of concentrated $\mathrm{HClO}_{4}$ $(2.0 \mathrm{~mL})$ and water $(20 \mathrm{~mL})$, the resulting solution in an open beaker was slowly evaporated at room temperature to precipitate an orange solid. The product was collected by filtration and then dissolved in $1.0 \times 10^{-3} \mathrm{M} \mathrm{HClO}_{4}$ acetonitrile solution $(\mathrm{ca} .10 \mathrm{~mL})$. The solution was filtered to remove any solid. After the addition of water $(10 \mathrm{~mL})$ to the filtrate, the solution was evaporated at room temperature. The orange solid formed was filtered, washed with methanol, and dried in air. Yield: $\sim 40 \%$ based on $\mathrm{L}^{10}$. Anal. Found: C, 40.43; H, 7.44; N, 11.05. Calc. for $\mathrm{C}_{22} \mathrm{H}_{43} \mathrm{~N}_{5} \mathrm{Cl}_{2} \mathrm{NiO}_{9}$ $\left(\left[\mathrm{NiL}^{2}\right]\left(\mathrm{ClO}_{4}\right)_{2} \cdot \mathrm{H}_{2} \mathrm{O}\right) . \mathrm{C}, 40.58 ; \mathrm{H}, 6.66 ; \mathrm{N}, 10.75 \%$. FAB
Mass $(m / z): 531.9$ for $\left[\mathrm{NiL}^{2}+\mathrm{ClO}_{4}\right]^{+} ; 431.9$ for $\left[\mathrm{NiL}^{2}-\mathrm{H}\right]^{+}$. IR $\left(\mathrm{cm}^{-1}\right): 3515\left(v_{\mathrm{O}-\mathrm{H}}, \mathrm{H}_{2} \mathrm{O}\right), 3214\left(v_{\mathrm{N}-\mathrm{H}}\right), 3165\left(v_{\mathrm{N}-\mathrm{H}}\right), 3087$ $\left(v_{\mathrm{N}-\mathrm{H}}\right), 2250\left(v_{\mathrm{C} \equiv \mathrm{N}}\right)$, and $1620\left\{\delta\left(\mathrm{H}_{2} \mathrm{O}\right)\right\} .{ }^{13} \mathrm{C}-\mathrm{NMR}\left(\mathrm{CD}_{3} \mathrm{NO}_{2}\right)$ : 16.2, 16.5, 25.2, 25.3, 25.4, 25.7, 26.1, 30.2, 30.7, 30.9, 31.5, $33.1,39.1,41.4,47.3,48.1,51.3,59.2,66.9,76.8\left(-\mathrm{CH}_{2} \mathrm{CN}\right)$, $114.5\left(-\mathrm{CH}_{2} \mathrm{CN}\right) \mathrm{ppm}$.

Preparation of $\left[\mathrm{CuL}^{2}\right]\left(\mathrm{ClO}_{4}\right)_{2} \cdot \mathrm{H}_{2} \mathrm{O}$. This complex was prepared by a method similar to that for $\left[\mathrm{NiL}^{2}\right]\left(\mathrm{ClO}_{4}\right)_{2} \cdot \mathrm{H}_{2} \mathrm{O}$ except that $\mathrm{Cu}(\mathrm{OAc})_{2} \cdot \mathrm{H}_{2} \mathrm{O}(2.0 \mathrm{~g}, 10 \mathrm{mmol})$ was reacted instead of $\mathrm{Ni}(\mathrm{OAc})_{2} \cdot 4 \mathrm{H}_{2} \mathrm{O}$. The red-purple solid was recrystallized from $1.0 \times 10^{-3} \mathrm{M} \mathrm{HClO}_{4}$ acetonitrile-water (1:2) solution. Yield: $\sim 40 \%$ basedon $\mathrm{L}^{10}$. Anal. Found: $\mathrm{C}$, 40.78; H, 6.88; N, 10.40. Calc. for $\mathrm{C}_{22} \mathrm{H}_{43} \mathrm{~N}_{5} \mathrm{Cl}_{2} \mathrm{CuO}_{9}$ : C, 40.28; H, 6.61; N, 10.67\%. FAB Mass $(m / z): 536.9$ for $\left[\mathrm{CuL}^{2}\right.$ $\left.+\mathrm{ClO}_{4}\right]^{+} ; 438.0$ for $\left[\mathrm{CuL}^{2}-\mathrm{H}\right]^{+}$. IR $\left(\mathrm{cm}^{-1}\right): 3515\left(v_{\mathrm{O}-\mathrm{H}}, \mathrm{H}_{2} \mathrm{O}\right)$, $3210\left(v_{\mathrm{N}-\mathrm{H}}\right), 3185\left(v_{\mathrm{N}-\mathrm{H}}\right), 3124\left(v_{\mathrm{N}-\mathrm{H}}\right), 2250\left(v_{\mathrm{C}=\mathrm{N}}\right)$, and 1620 $\left[\delta\left(\mathrm{H}_{2} \mathrm{O}\right)\right]$.

Preparation of $\left[\mathrm{Ni}\left(\mathrm{HL}^{3}\right)\left(\mathrm{H}_{2} \mathrm{O}\right)\right]\left(\mathrm{ClO}_{4}\right)_{2}$. The $\mathrm{pH}$ of a water-acetonitrile $(1: 2)$ solution $(20 \mathrm{~mL})$ of $\left[\mathrm{NiL}^{2}\right]\left(\mathrm{ClO}_{4}\right)_{2} \cdot \mathrm{H}_{2} \mathrm{O}$ $(0.5 \mathrm{~g})$ was adjusted to $\geq 8$ through the addition of $0.1 \mathrm{M}$ $\mathrm{NaOH}$ solution. The solution was stirred at room temperature for $5 \mathrm{~min}$. The resulting pale purple solution was filtered to remove any solid, and then concentrated $\mathrm{HClO}_{4}$ $(1.0 \mathrm{~mL})$ was added to the filtrate. The mixture was evaporated at room temperature to produce a pale purple solid. The product was collected by filtration, washed with cold methanol, and dried in air. It was recrystallized by the addition of $\mathrm{HClO}_{4}$ to hot a water-acetonitrile (1:1) solution of the crude product. Yield: $\sim 70 \%$. Anal. Found: C, 39.47; $\mathrm{H}, 6.51 ; \mathrm{N}, 10.56$. Calc. for $\mathrm{C}_{22} \mathrm{H}_{45} \mathrm{~N}_{5} \mathrm{Cl}_{2} \mathrm{NiO}_{10}$ : C, 39.48; $\mathrm{H}$, $6.78 ; \mathrm{N}, 10.46 \%$. FAB Mass $(\mathrm{m} / \mathrm{z}): 550.2$ for $\left[\mathrm{Ni}\left(\mathrm{HL}^{3}\right)+\right.$ $\left.\mathrm{ClO}_{4}\right]^{+} ; 450.2$ for $\left[\mathrm{Ni}\left(\mathrm{HL}^{3}\right)-\mathrm{H}\right]^{+}$. IR $\left(\mathrm{cm}^{-1}\right): 3500\left(v_{\mathrm{O}-\mathrm{H}}, \mathrm{H}_{2} \mathrm{O}\right)$, $3397\left(v_{\mathrm{N}-\mathrm{H}}\right), 3387\left(v_{\mathrm{N}-\mathrm{H}}\right), 3340\left(v_{\mathrm{N}-\mathrm{H}}\right), 3290\left(v_{\mathrm{N}-\mathrm{H}}\right), 3257\left(v_{\mathrm{N}-\mathrm{H}}\right)$, $3238\left(v_{\mathrm{N}-\mathrm{H}}\right), 3190\left(v_{\mathrm{N}-\mathrm{H}}\right), 1670\left(v_{\mathrm{C}=\mathrm{O}}\right), 1620\left[\delta\left(\mathrm{H}_{2} \mathrm{O}\right)\right]$, and $1600\left[\delta\left(\mathrm{NH}_{2}\right)\right] . \mu_{\mathrm{eff}}=2.80 \mu_{\mathrm{B}}$.

This complex was also prepared by stirring a warm $(\sim 50$ $\left.{ }^{\circ} \mathrm{C}\right)$ basic $(\mathrm{pH} \geq 10)$ water-acetonitrile $(1: 1)$ solution $(20 \mathrm{~mL})$ of $\left[\mathrm{NiL}^{4}\left(\mathrm{H}_{2} \mathrm{O}\right)\right]\left(\mathrm{ClO}_{4}\right)_{2}(0.5 \mathrm{~g})$ for $10 \mathrm{~min}$. the addition of concentrated of $\mathrm{HClO}_{4}(1.0 \mathrm{~mL})$ to the resulting solution produced the purple solid.

Preparation of $\left[\mathrm{NiL}^{3}\left(\mathrm{H}_{2} \mathrm{O}\right)\right] \mathbf{C l O}_{4}$. The $\mathrm{pH}$ of a wateracetonitrile $(1: 1)$ solution $(20 \mathrm{~mL})$ of $\left[\mathrm{Ni}\left(\mathrm{HL}^{3}\right)\left(\mathrm{H}_{2} \mathrm{O}\right)\right]\left(\mathrm{ClO}_{4}\right)_{2}$ $(0.5 \mathrm{~g})$ was adjusted to $\geq 12$ through the addition of $1.0 \mathrm{M}$ $\mathrm{NaOH}$ solution. The solution was evaporated at room temperature to produce a dark purple solid. The product was collected by filtration, washed with cold water, and dried in air. Yield: $\sim 80 \%$. Found: C, 45.69; H, 7.34; N, 11.92. Calc. for $\mathrm{C}_{22} \mathrm{H}_{44} \mathrm{~N}_{5} \mathrm{ClNiO}_{6}$ : C, 46.46; H, 7.80; N, 12.31\%. FAB Mass $(m / z): 549.9$ for $\left[\mathrm{NiL}^{3}+\mathrm{ClO}_{4}\right]^{+} ; 450.0$ for $\left[\mathrm{NiL}^{3}-\mathrm{H}\right]^{+}$. IR $\left(\mathrm{cm}^{-1}\right): 3480\left(v_{\mathrm{O}-\mathrm{H}}, \mathrm{H}_{2} \mathrm{O}\right), 3310\left(v_{\mathrm{N}-\mathrm{H}}\right), 3300\left(v_{\mathrm{N}-\mathrm{H}}\right), 3252$ $\left(v_{\mathrm{N}-\mathrm{H}}\right), 3200\left(v_{\mathrm{N}-\mathrm{H}}\right), 1620\left[\delta\left(\mathrm{H}_{2} \mathrm{O}\right)\right]$, and $1570\left\{v_{(\mathrm{CONH})}\right\} \cdot \mu_{\text {eff }}$ $=2.78 \mu_{\mathrm{B}}$.

Preparation of $\left[\mathrm{Cu}\left(\mathrm{HL}^{3}\right)\right]\left(\mathrm{ClO}_{4}\right)_{2}$. This complex was prepared by a method similar to that for $\left[\mathrm{Ni}\left(\mathrm{HL}^{3}\right)\left(\mathrm{H}_{2} \mathrm{O}\right)\right]\left(\mathrm{ClO}_{4}\right)_{2}$ except that $\left[\mathrm{CuL}^{2}\right]\left(\mathrm{ClO}_{4}\right)_{2}(0.5 \mathrm{~g})$ was reacted instead of $\left[\mathrm{NiL}^{2}\right]\left(\mathrm{ClO}_{4}\right)_{2} \cdot \mathrm{H}_{2} \mathrm{O}$. The purple solid was recrystallized from hot acetonitrile-water (1:2) solution. Yield: $\sim 70 \%$. Found: C, 
40.90; $\mathrm{H}, 6.34 ; \mathrm{N}, 10.79$. Calc. for $\mathrm{C}_{22} \mathrm{H}_{43} \mathrm{~N}_{5} \mathrm{Cl}_{2} \mathrm{NiO}_{9}$ : C, 40.28; H, 6.61; N, 10.67\%. FAB Mass $(\mathrm{m} / \mathrm{z})$ : 554.9 for $\left[\mathrm{Cu}\left(\mathrm{HL}^{3}\right)+\mathrm{ClO}_{4}\right]^{+} ; 456.0$ for $\left[\mathrm{Cu}\left(\mathrm{HL}^{3}\right)-\mathrm{H}\right]^{+}$. IR $\left(\mathrm{cm}^{-1}\right)$ : $3351\left(v_{\mathrm{N}-\mathrm{H}}\right), 3320\left(v_{\mathrm{N}-\mathrm{H}}\right), 3243\left(v_{\mathrm{N}-\mathrm{H}}\right), 3202\left(v_{\mathrm{N}-\mathrm{H}}\right), 1680$ $\left(v_{\mathrm{C}=\mathrm{O}}\right)$, and $1600\left[\delta\left(\mathrm{NH}_{2}\right)\right]$.

This complex was also prepared by stirring a warm $(\sim 50$ $\left.{ }^{\circ} \mathrm{C}\right)$ basic $(\mathrm{pH} \geq 10)$ water-acetonitrile $(1: 1)$ solution $(20 \mathrm{~mL})$ of $\left[\mathrm{CuL}^{4}\right]\left(\mathrm{ClO}_{4}\right)_{2}(0.5 \mathrm{~g})$ for $10 \mathrm{~min}$. The addition of concentrated of $\mathrm{HClO}_{4}(1.0 \mathrm{~mL})$ to the resulting solution produced the purple solid.

Preparation of $\left[\mathrm{NiL}^{4}\left(\mathrm{H}_{2} \mathrm{O}\right)\right]\left(\mathrm{ClO}_{4}\right)_{2}$. To a methanolacetonitrile $(1: 3)$ solution $(20 \mathrm{~mL})$ of $\left[\mathrm{NiL}^{2}\right]\left(\mathrm{ClO}_{4}\right)_{2} \cdot \mathrm{H}_{2} \mathrm{O}$ $(0.5 \mathrm{~g})$ was added triethylamine $(0.1 \mathrm{~mL})$. The resulting solution was refluxed for $5 \mathrm{~min}$. During which time, the orange solution turned to pale purple. After the addition of concentrated $\mathrm{HClO}_{4}(1.0 \mathrm{~mL})$ and water $(10 \mathrm{~mL})$ at room temperature, the mixture was evaporated to precipitate a purple solid. The product was collected by filtration, washed with cold methanol, and dried in air. It was recrystallized from hot water-acetonitrile (1:1) mixture. Yield: $\sim 70 \%$. Anal. Found: C, 40.90; H, 7.45; N, 10.09. Calc. for $\mathrm{C}_{23} \mathrm{H}_{47} \mathrm{~N}_{5} \mathrm{Cl}_{2} \mathrm{NiO}_{10}$ : C, 40.43; H, 6.93; N, 10.25\%. FAB Mass $(m / z): 564.2$ for $\left[\mathrm{NiL}^{4}+\mathrm{ClO}_{4}\right]^{+} ; 464.3$ for $\left[\mathrm{NiL}^{4}-\mathrm{H}\right]^{+}$. IR $\left(\mathrm{cm}^{-1}\right): 3500\left(v_{\mathrm{O}-\mathrm{H}}, \mathrm{H}_{2} \mathrm{O}\right), 3290\left(v_{\mathrm{N}-\mathrm{H}}\right), 3250\left(v_{\mathrm{N}-\mathrm{H}}\right), 3232$ $\left(v_{\mathrm{N}-\mathrm{H}}\right), 1666\left(v_{\mathrm{C}=\mathrm{N}}\right)$, and $1620\left[\delta\left(\mathrm{H}_{2} \mathrm{O}\right)\right] . \mu_{\mathrm{eff}}=2.76 \mu_{\mathrm{B}}$.

Preparation of $\left[\mathrm{CuL}^{4}\right]\left(\mathrm{ClO}_{4}\right)_{2}$. This complex was prepared in a methanol-acetonitrile $(1: 3)$ solution $(20 \mathrm{~mL})$ by a method similar to that for $\left[\mathrm{NiL}^{4}\left(\mathrm{H}_{2} \mathrm{O}\right)\right]\left(\mathrm{ClO}_{4}\right)_{2}$ except that $\left[\mathrm{CuL}^{2}\right]\left(\mathrm{ClO}_{4}\right)_{2}(0.5 \mathrm{~g})$ was reacted instead of $\left[\mathrm{NiL}^{2}\right]\left(\mathrm{ClO}_{4}\right)_{2} \cdot \mathrm{H}_{2} \mathrm{O}$. The purple solid was recrystallized from hot acetonitrilewater (1:2) solution. Yield: $\sim 70 \%$. Anal. Found: C, 40.25; H, 7.01; N, 9.93. Calc. for $\mathrm{C}_{23} \mathrm{H}_{47} \mathrm{~N}_{5} \mathrm{Cl}_{2} \mathrm{CuO}_{10}$ : C, 40.15; $\mathrm{H}$, $6.88 ; \mathrm{N}, 10.18 \%$. FAB Mass $(\mathrm{m} / \mathrm{z}): 569.1$ for $\left[\mathrm{CuL}^{4}+\right.$ $\left.\mathrm{ClO}_{4}\right]^{+} ; 470.2$ for $\left[\mathrm{CuL}^{4}-\mathrm{H}\right]^{+}$. IR $\left(\mathrm{cm}^{-1}\right): 3500\left(v_{\mathrm{O}-\mathrm{H}}, \mathrm{H}_{2} \mathrm{O}\right)$,
$3300\left(v_{\mathrm{N}-\mathrm{H}}\right), 3200\left(v_{\mathrm{N}-\mathrm{H}}, b r\right), 1665\left(v_{\mathrm{C}=\mathrm{N}}\right)$, and $1620\left[\delta\left(\mathrm{H}_{2} \mathrm{O}\right)\right]$.

\section{Results and Discussion}

Synthesis. The mono- $N$-hydroxyethylated macrocycle $\mathrm{HL}^{9}$ has been prepared by the direct reaction of $\mathrm{L}^{1}$ with $\mathrm{BrCH}_{2} \mathrm{CH}_{2} \mathrm{OH} .{ }^{15}$ However, unexpectedly, our initial attempts to prepare $\mathrm{L}^{2}$ from the reaction of $\mathrm{L}^{1}$ with $\mathrm{BrCH}_{2} \mathrm{CN}$ in a $1: 1$ molar ratio were unsuccessful; the solid isolated from the reaction solution was found to be a mixture of $\mathrm{L}^{5}$ bearing two $\mathrm{N}-\mathrm{CH}_{2} \mathrm{CN}$ pendant arms and the reactant $\mathrm{L}^{1}$. Therefore, the synthesis of $\mathrm{L}^{2}$ begins with the preparation of $\mathrm{L}^{10}$ where two amino groups are protected. The reaction of $\mathrm{L}^{10}$ with $\mathrm{BrCH}_{2} \mathrm{CN}$ produces the macropolycycle $\mathrm{L}^{11}$ bearing only one $\mathrm{N}-\mathrm{CH}_{2} \mathrm{CN}$ pendant arm. The macrocycle $\mathrm{L}^{2}$ could be prepared as its nickel(II) or copper(II) complex, $\left[\mathrm{ML}^{2}\right]^{2+}$ $(\mathrm{M}=\mathrm{Ni}(\mathrm{II})$ or $\mathrm{Cu}(\mathrm{II}))$, by the reaction of $\mathrm{L}^{11}$ with the metal ion in acetonitrile. The nickel(II) and copper(II) complexes of $\mathrm{HL}^{3}$ and $\mathrm{L}^{4}$ bearing one $\mathrm{N}-\mathrm{CH}_{2} \mathrm{CONH}_{2}$ or $\mathrm{N}$ $\mathrm{CH}_{2} \mathrm{C}(=\mathrm{NH}) \mathrm{OMe}$ pendant arm were prepared by the reaction of $\left[\mathrm{ML}^{2}\right]^{2+}$ with water or methanol. The reactivity of $\left[\mathrm{ML}^{2}\right]^{2+}$ in water or methanol is not quite different from that reported for $\left[\mathrm{ML}^{5}\right]^{2+} \cdot{ }^{17,23}$ The preparation of nickel(II) and copper(II) complexes of $\mathrm{HL}^{3}$ can also be achieved by the hydrolysis of the corresponding complexes of $\mathrm{L}^{4}$ in basic aqueous solutions. The synthetic procedures for the complexes of $\mathrm{L}^{2}-\mathrm{L}^{4}$ are shown in Scheme 1.

In basic aqueous solutions, $\left[\mathrm{Ni}\left(\mathrm{HL}^{3}\right)\left(\mathrm{H}_{2} \mathrm{O}\right)\right]\left(\mathrm{ClO}_{4}\right)_{2}$ readily undergoes deprotonation to yield $\left[\mathrm{NiL}^{3}\left(\mathrm{H}_{2} \mathrm{O}\right)\right] \mathrm{ClO}_{4}\left(\mathrm{~L}^{3}=\mathrm{a}\right.$ deprotonated form of $\left.\mathrm{HL}^{3}\right)$. The isolation of $\left[\mathrm{NiL}^{3}\left(\mathrm{H}_{2} \mathrm{O}\right)\right] \mathrm{ClO}_{4}$ as a solid in the present work is quite interesting, because such deprotonation is not observed for other related macrocyclic complexes, such as $\left[\mathrm{Cu}\left(\mathrm{HL}^{3}\right)\right]\left(\mathrm{ClO}_{4}\right)_{2}$ and $\left[\mathrm{NiL}^{6}\right]\left(\mathrm{ClO}_{4}\right)_{2}$. In the case of $\left[\mathrm{Cu}\left(\mathrm{HL}^{3}\right)\right]\left(\mathrm{ClO}_{4}\right)_{2}$ or $\left[\mathrm{NiL}^{6}\right]\left(\mathrm{ClO}_{4}\right)_{2}$, any

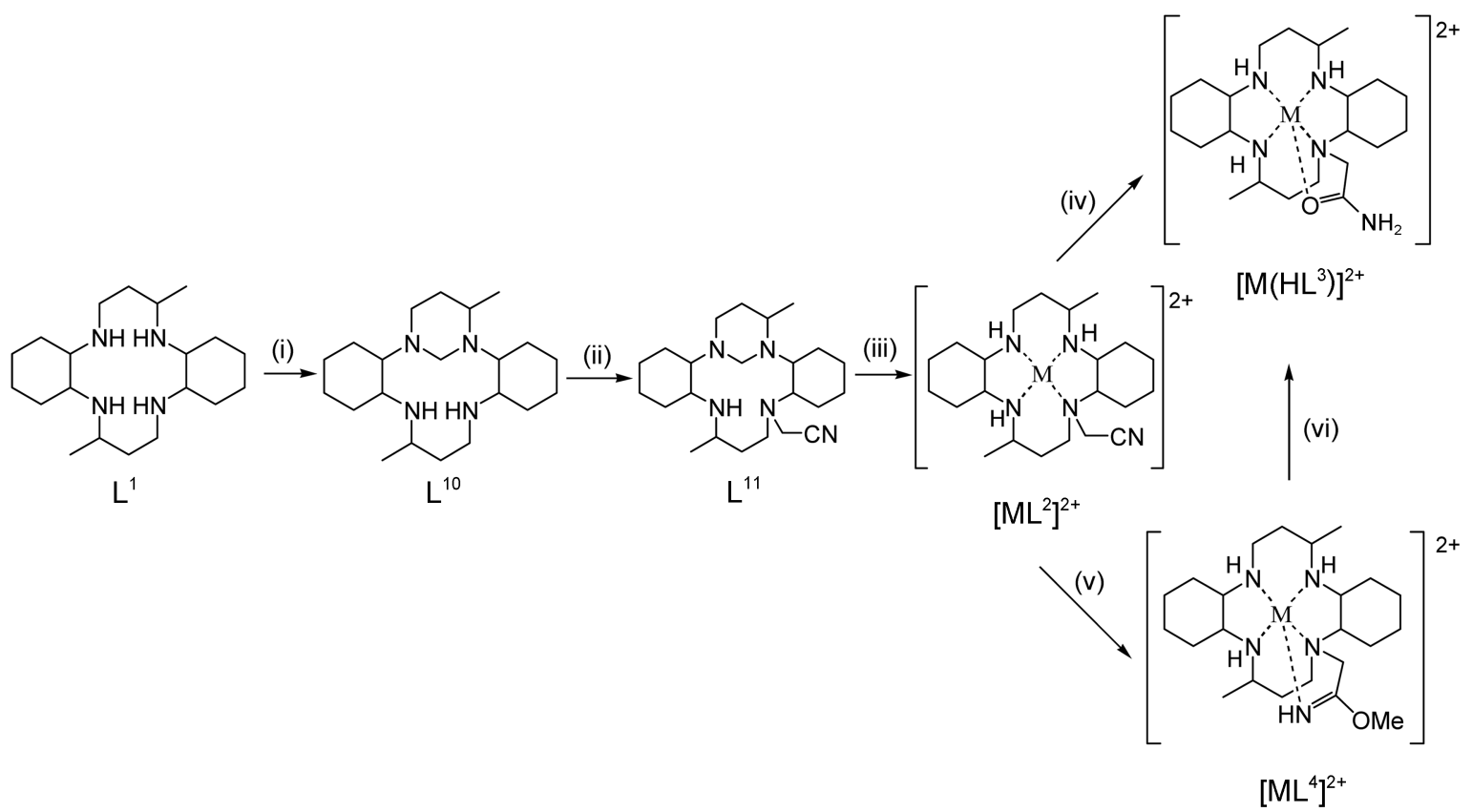

Scheme 1. Reagents and Conditions: (i) $\mathrm{HCHO} / \mathrm{MeOH}$; (ii) $\mathrm{BrCH}_{2} \mathrm{CN} / \mathrm{CHCl}_{3}$; (iii) $\mathrm{M}^{2+} / \mathrm{CH}_{3} \mathrm{CN}$; (iv) $\mathrm{H}_{2} \mathrm{O}$ (pH $\geq 8$ ); (v) $\mathrm{MeOH} / \mathrm{Et}{ }_{3} \mathrm{~N}$; (vi) $\mathrm{H}_{2} \mathrm{O}(\mathrm{pH} \geq 8)$. The coordinated solvent molecule is omitted for clarity. 
Table 1. Electronic Absorption Spectra and Molar Conductance Data ${ }^{a}$

\begin{tabular}{|c|c|c|c|c|c|c|c|}
\hline \multirow{2}{*}{$\frac{\text { Complex }}{\left[\mathrm{NiL}^{1}\right]\left(\mathrm{ClO}_{4}\right)_{2}{ }^{b}}$} & \multicolumn{3}{|c|}{$\lambda_{\max }, \mathrm{nm}\left(\varepsilon, \mathrm{M}^{-1} \mathrm{~cm}^{-1}\right)$} & \multicolumn{4}{|c|}{$\Lambda_{\mathrm{M}},\left(\Omega^{-1} \mathrm{~cm}^{2} \mathrm{~mol}^{-1}\right)$} \\
\hline & $465(66)^{c}$ & & & & & & \\
\hline$\left[\mathrm{NiL}^{2}\right]\left(\mathrm{ClO}_{4}\right)_{2}$ & $478(100)$ & $478(82)^{c}$ & $477(100)^{d}$ & $477^{e}$ & 125 & $250^{c}$ & $45^{d}$ \\
\hline \multirow[t]{3}{*}[\mathrm{Ni}(\mathrm{HL}^{3})(\mathrm{H}_{2}\mathrm{O})]{$\left(\mathrm{ClO}_{4}\right)_{2}$} & & $523(7.7)$ & $695(2.6)$ & & 110 & $240^{c}$ & $50^{d}$ \\
\hline & $335(12)^{c}$ & $506(7.4)^{c}$ & $724(2.1)^{c}$ & & & & \\
\hline & $345(14)^{d}$ & $532(7.5)^{d}$ & $700(2.7)^{d}$ & & & & \\
\hline \multirow[t]{3}{*}[\mathrm{NiL}^{3}(\mathrm{H}_{2}\mathrm{O})]{$\left(\mathrm{ClO}_{4}\right)_{2}$} & & $527(11.6)$ & $740(3.1)$ & & 75 & $130^{c}$ & $24^{d}$ \\
\hline & $354(42)^{c}$ & $556(25)^{c}$ & $750(6.7)^{c}$ & & & & \\
\hline & $360(73)^{d}$ & $568(40)^{d}$ & $750(8.0)^{d}$ & & & & \\
\hline \multirow[t]{3}{*}[\mathrm{NiL}^{4}(\mathrm{H}_{2}\mathrm{O})]{$\left(\mathrm{ClO}_{4}\right)_{2}$} & & $530(20)$ & $710(4.5)$ & & 130 & $233^{c}$ & $55^{d}$ \\
\hline & $333(13)^{c}$ & $515(9.1)^{c}$ & $740(3.6)^{c}$ & & & & \\
\hline & $345(16)^{d}$ & $532(18)^{d}$ & $710(4.5)^{d}$ & & & & \\
\hline$\left[\mathrm{NiL}^{5}\right]\left(\mathrm{ClO}_{4}\right)_{2}^{f}$ & $492(77)^{d}$ & & & & & & \\
\hline$\left[\mathrm{CuL}^{1}\right]\left(\mathrm{ClO}_{4}\right)_{2}{ }^{b}$ & $487(113)^{c}$ & & & & & & \\
\hline$\left[\mathrm{CuL}^{2}\right]\left(\mathrm{ClO}_{4}\right)_{2} \cdot \mathrm{H}_{2} \mathrm{O}$ & 497(137) & $527(170)^{c}$ & $532(165)^{d}$ & $495^{e}$ & 120 & $220^{c}$ & $55^{d}$ \\
\hline$\left[\mathrm{Cu}\left(\mathrm{HL}^{3}\right)\right]\left(\mathrm{ClO}_{4}\right)_{2}$ & $540(125)$ & $540(126)^{c}$ & $537(130)^{d}$ & $545^{e}$ & 130 & $250^{c}$ & $60^{d}$ \\
\hline$\left[\mathrm{CuL}^{4}\right]\left(\mathrm{ClO}_{4}\right)_{2}$ & $553(120)$ & $552(122)^{c}$ & $570(195)^{d}$ & $553^{e}$ & 134 & $235^{c}$ & $56^{d}$ \\
\hline$\left[\mathrm{CuL}^{5}\right]\left(\mathrm{ClO}_{4}\right)_{2}{ }^{f}$ & $535(230)^{c}$ & $500^{e}$ & & & & & \\
\hline
\end{tabular}

${ }^{a}$ Measured in nitromethane at room temperature unless otherwise specified. ${ }^{b}$ Ref. $24 .{ }^{c}$ Measured in acetonitrile. ${ }^{b}$ Measured in DMSO. ${ }^{e}$ Measured in Nujol mull. ${ }^{f}$ Ref. 17.

deprotonated form could not be prepared under similar experimental conditions. It is obvious that the acidity of the $\mathrm{N}-\mathrm{CH}_{2} \mathrm{CONH}_{2}$ group in $\left[\mathrm{Ni}\left(\mathrm{HL}^{3}\right)\left(\mathrm{H}_{2} \mathrm{O}\right)\right]\left(\mathrm{ClO}_{4}\right)_{2}$ is stronger than that attached to $\left[\mathrm{Cu}\left(\mathrm{HL}^{3}\right)\right]\left(\mathrm{ClO}_{4}\right)_{2}$ or $\left[\mathrm{NiL}^{6}\right]\left(\mathrm{ClO}_{4}\right)_{2}$.

Spectra and Properties of $\left[\mathrm{NiL}^{2}\right]\left(\mathrm{ClO}_{4}\right)_{2} \cdot \mathrm{H}_{2} \mathrm{O}$ and $\left[\mathrm{CuL}^{2}\right]\left(\mathrm{ClO}_{4}\right)_{2} \cdot \mathrm{H}_{2} \mathrm{O}$. The FAB mass spectrum of $\left[\mathrm{NiL}^{2}\right]-$ $\left(\mathrm{ClO}_{4}\right)_{2} \cdot \mathrm{H}_{2} \mathrm{O}$ shows two groups of peaks at $m / z 531.9\left\{\left[\mathrm{NiL}^{2}\right.\right.$ $\left.\left.+\mathrm{ClO}_{4}\right]^{+}\right\}$and $431.9\left\{\left[\mathrm{NiL}^{2}-\mathrm{H}\right]^{+}\right\}$. The spectrum of $\left[\mathrm{CuL}^{2}\right]-$ $\left(\mathrm{ClO}_{4}\right)_{2} \cdot \mathrm{H}_{2} \mathrm{O}$ also shows two groups of peaks corresponding to $\left[\mathrm{CuL}^{2}+\mathrm{ClO}_{4}\right]^{+}$and $\left\{\left[\mathrm{CuL}^{2}-\mathrm{H}\right]^{+}\right.$fragments at $\mathrm{m} / z 536.9$ and 438.0 , respectively. In the infrared spectra of the complexes, peaks corresponding to $v_{\mathrm{N}-\mathrm{H}}$ of the coordinated amino groups are observed at $3120-3220 \mathrm{~cm}^{-1}$. The spectra also show $v_{\mathrm{C} \equiv \mathrm{N}}$ of the pendant arm at $c a .2250 \mathrm{~cm}^{-1}$. The nickel(II) complex was found to be a diamagnetic substance. ${ }^{13} \mathrm{C}-\mathrm{NMR}$ spectrum (see Experimental Section) of the nickel(II) complex also corresponds to the ligand structure of $\mathrm{L}^{2}$, in which one cyanomethyl group is attached to the sterically less hindered nitrogen atom. The electronic absorption spectra (Table 1) of $\left[\mathrm{NiL}^{2}\right]\left(\mathrm{ClO}_{4}\right)_{2} \cdot \mathrm{H}_{2} \mathrm{O}$ measured in Nujol mull and various solvents show a d-d transition band at $c a$. $477 \mathrm{~nm}$. The wavelength is intermediate between those of the square-planar complexes $\left[\mathrm{NiL}^{1}\right]\left(\mathrm{ClO}_{4}\right)_{2}(465 \mathrm{~nm})$ and $\left[\mathrm{NiL}^{5}\right]\left(\mathrm{ClO}_{4}\right)_{2}(492 \mathrm{~nm}){ }^{17,25}$ This corresponds to the general trend that stepwise alkylation to coordinated nitrogen atoms of a 14-membered tetraaza macrocyclic nickel(II) complex weakens the ligand field strength. ${ }^{15,17,26}$ The visible absorption spectra of $\left[\mathrm{CuL}^{2}\right]\left(\mathrm{ClO}_{4}\right)_{2} \cdot \mathrm{H}_{2} \mathrm{O}$ measured in Nujol mull $(495 \mathrm{~nm})$ and nitromethane $(497 \mathrm{~nm})$ are also corresponding to the square-planar $\mathrm{Cu}-\mathrm{N}_{4}$ chromophore. ${ }^{15,17,25}$ Above results strongly indicate that $\left[\mathrm{NiL}^{2}\right]\left(\mathrm{ClO}_{4}\right)_{2} \cdot \mathrm{H}_{2} \mathrm{O}$ has a square-planer coordination geometry. The wavelengths measured in acetonitrile $(527 \mathrm{~nm})$ and DMSO $(532 \mathrm{~nm})$ are $c a .30 \mathrm{~nm}$ longer than those measured in Nujol mull and nitromethane, implicating the coordination of the solvent molecule in the solvents.

The nickel(II) and copper(II) complexes are soluble in acetonitrile, nitromethane, or DMSO, but are nearly insoluble in methanol or water at room temperature. The complexes are quite inert against hydrolysis in acidic aqueous solutions $(\mathrm{pH} \leq 6)$. As described above, however, they are readily hydrolyzed to $\left[\mathrm{Ni}\left(\mathrm{HL}^{3}\right)\left(\mathrm{H}_{2} \mathrm{O}\right)\right]^{2+}$ or $\left[\mathrm{Cu}\left(\mathrm{HL}^{3}\right)\right]^{2+}$ in basic aqueous solutions.

Spectra and Properties of $\left[\mathrm{Ni}\left(\mathrm{HL}^{3}\right)\left(\mathrm{H}_{2} \mathrm{O}\right)\right]\left(\mathrm{ClO}_{4}\right)_{2}$, $\left[\mathrm{Cu}\left(\mathrm{HL}^{3}\right)\right]\left(\mathrm{ClO}_{4}\right)_{2}$, and $\left[\mathrm{NiL}^{3}\left(\mathrm{H}_{2} \mathrm{O}\right)\right] \mathrm{ClO}_{4}$. Infrared spectra of $\left[\mathrm{Ni}\left(\mathrm{HL}^{3}\right)\left(\mathrm{H}_{2} \mathrm{O}\right)\right]\left(\mathrm{ClO}_{4}\right)_{2}$ and $\left[\mathrm{Cu}\left(\mathrm{HL}^{3}\right)\right]\left(\mathrm{ClO}_{4}\right)_{2}$ show several peaks corresponding to $\mathrm{v}_{\mathrm{N}-\mathrm{H}}$ of the coordinated amino and the amide groups at $3390-3190 \mathrm{~cm}^{-1}$. The spectra also show $v_{\mathrm{C}=\mathrm{O}}$ of the pendant arm at $c a .1670 \mathrm{~cm}^{-1}$. In the spectrum of $\left[\mathrm{NiL}^{3}\left(\mathrm{H}_{2} \mathrm{O}\right)\right] \mathrm{ClO}_{4}$, four peaks of $v_{\mathrm{N}-\mathrm{H}}$ are observed at 3310$3200 \mathrm{~cm}^{-1}$. The FAB mass spectra of the nickel(II) and copper(II) complexes show two groups of peaks corresponding to the fragments $\left[\mathrm{M}\left(\mathrm{HL}^{3}\right)+\mathrm{ClO}_{4}\right]^{+}$and $\left[\mathrm{M}\left(\mathrm{HL}^{3}\right)-\mathrm{H}\right]^{+}$ (see Experimental section). The magnetic moments $\left(\mu_{\mathrm{eff}}\right)$ of $\left[\mathrm{Ni}\left(\mathrm{HL}^{3}\right)\left(\mathrm{H}_{2} \mathrm{O}\right)\right]\left(\mathrm{ClO}_{4}\right)_{2}$ and $\left[\mathrm{NiL}^{3}\left(\mathrm{H}_{2} \mathrm{O}\right)\right] \mathrm{ClO}_{4}$ in the solid states are 2.80 and $2.78 \mu_{\mathrm{B}}$, respectively, at room temperature. This is consistent with a $d^{8}$ electronic configuration of the complexes in octahedral coordination geometry. The electronic absorption spectrum (Table 1) of $\left[\mathrm{Ni}\left(\mathrm{HL}^{3}\right)\left(\mathrm{H}_{2} \mathrm{O}\right)\right]-$ $\left(\mathrm{ClO}_{4}\right)_{2}$ measured in Nujol mull shows three bands at $c a .340$ $\left({ }^{3} \mathrm{~B}_{1 \mathrm{~g}} \rightarrow{ }^{3} \mathrm{E}_{\mathrm{g}}(\mathrm{P})\right), 510\left({ }^{3} \mathrm{~B}_{1 \mathrm{~g}} \rightarrow{ }^{3} \mathrm{E}_{\mathrm{g}}\right)$, and $690\left({ }^{3} \mathrm{~B}_{1 \mathrm{~g}} \rightarrow{ }^{3} \mathrm{~B}_{2 \mathrm{~g}}+\right.$ $\left.{ }^{3} \mathrm{~B}_{1 \mathrm{~g}} \rightarrow{ }^{3} \mathrm{~A}_{2 \mathrm{~g}}\right) \mathrm{nm}$, indicating that the complex has octahedral coordination geometry in the solid state; ${ }^{10,14,17,27}$ water molecule as well as the pendant amide group is involved in coordination. The spectra measured in various solvents are similar to that measured in Nujol mull. The spectra of $\left[\mathrm{NiL}^{3}\left(\mathrm{H}_{2} \mathrm{O}\right)\right] \mathrm{ClO}_{4}$ measured in various solvents are comparable with those of $\left[\mathrm{Ni}\left(\mathrm{HL}^{3}\right)\left(\mathrm{H}_{2} \mathrm{O}\right)\right]\left(\mathrm{ClO}_{4}\right)_{2}$. However, the 
wavelength and molar absorption coefficient of each band for $\left[\mathrm{NiL}^{3}\left(\mathrm{H}_{2} \mathrm{O}\right)\right] \mathrm{ClO}_{4}$ are somewhat longer and larger, respectively, that those for $\left[\mathrm{Ni}\left(\mathrm{HL}^{3}\right)\left(\mathrm{H}_{2} \mathrm{O}\right)\right]\left(\mathrm{ClO}_{4}\right)_{2}$. The electronic absorption spectra of $\left[\mathrm{Cu}\left(\mathrm{HL}^{3}\right)\right]\left(\mathrm{ClO}_{4}\right)_{2}$ measured in Nujol mull and various solvents show a d-d transition band at $c a$. $540 \mathrm{~nm}\left(\varepsilon=125-130 \mathrm{M}^{-1} \mathrm{~cm}^{-1}\right)$, supporting the suggestion that the complex has square-pyramidal coordination geometry. ${ }^{15,20}$ The copper(II) complex, unlike the nickel(II) complexes, is reluctant to form octahedral structure. This may be closely related to Jahn-Teller distortion of octahedral copper(II) complexes. The values of the molar conductance (Table 1) measured in various solvents indicate that $\left[\mathrm{Ni}\left(\mathrm{HL}^{3}\right)\left(\mathrm{H}_{2} \mathrm{O}\right)\right]\left(\mathrm{ClO}_{4}\right)_{2}$ (or $\left.\left[\mathrm{Cu}\left(\mathrm{HL}^{3}\right)\right]\left(\mathrm{ClO}_{4}\right)_{2}\right)$ and $\left[\mathrm{NiL}^{3}\left(\mathrm{H}_{2} \mathrm{O}\right)\right] \mathrm{ClO}_{4}$ are $1: 2$ and $1: 1$ electrolytes, respectively. The deprotonated complex $\left[\mathrm{NiL}^{3}\left(\mathrm{H}_{2} \mathrm{O}\right)\right] \mathrm{ClO}_{4}$ as well as $\left[\mathrm{Ni}\left(\mathrm{HL}^{3}\right)\left(\mathrm{H}_{2} \mathrm{O}\right)\right]\left(\mathrm{ClO}_{4}\right)_{2}$ and $\left[\mathrm{Cu}\left(\mathrm{HL}^{3}\right)\right]\left(\mathrm{ClO}_{4}\right)_{2}$ is quite stable in the solid state and in pure water, acetonitrile, or DMSO. Both $\left[\mathrm{Ni}\left(\mathrm{HL}^{3}\right)\left(\mathrm{H}_{2} \mathrm{O}\right)\right]\left(\mathrm{ClO}_{4}\right)_{2}$ and $\left[\mathrm{Cu}\left(\mathrm{HL}^{3}\right)\right]\left(\mathrm{ClO}_{4}\right)_{2}$ are also stable in acidic aqueous solutions.

Spectra and Properties of $\left[\mathrm{NiL}^{4}\left(\mathrm{H}_{2} \mathrm{O}\right)\right]\left(\mathrm{ClO}_{4}\right)_{2}$ and $\left[\mathrm{CuL}^{4}\right]\left(\mathrm{ClO}_{4}\right)_{2}$. The FAB mass spectrum of $\left[\mathrm{NiL}^{4}\left(\mathrm{H}_{2} \mathrm{O}\right)\right]-$ $\left(\mathrm{ClO}_{4}\right)_{2}$ shows two groups of peaks at $m / z 564.2\left\{\mathrm{NiL}^{4}+\right.$ $\left.\left.\mathrm{ClO}_{4}\right]^{+}\right\}$and $464.3\left\{\left[\mathrm{NiL}^{4}-\mathrm{H}\right]^{+}\right\}$. In the spectrum of $\left[\mathrm{CuL}^{4}\right]\left(\mathrm{ClO}_{4}\right)_{2}$, two groups of peaks corresponding to $\left[\mathrm{CuL}^{4}\right.$ $\left.+\mathrm{ClO}_{4}\right]^{+}$and $\left[\mathrm{CuL}^{4}-\mathrm{H}\right]^{+}$fragments are observed at $\mathrm{m} / \mathrm{z}$ 569.1 and 470.2 , respectively. Infrared spectra of the complexes show several peaks of $v_{\mathrm{N}-\mathrm{H}}$ at $3300-3200 \mathrm{~cm}^{-1}$. The spectra also show $v_{\mathrm{C}=\mathrm{N}}$ of the coordinated $\mathrm{N}-\mathrm{CH}_{2} \mathrm{C}(=\mathrm{NH}) \mathrm{OCH}_{3}$ group at $c a .1665 \mathrm{~cm}^{-1}$. The electronic absorption spectra (Table 1) of $\left[\mathrm{NiL}^{4}\left(\mathrm{H}_{2} \mathrm{O}\right)\right]\left(\mathrm{ClO}_{4}\right)_{2}$ measured in various solvents are comparable with those of other octahedral complexes, such as $\left[\mathrm{Ni}\left(\mathrm{HL}^{3}\right)\left(\mathrm{H}_{2} \mathrm{O}\right)\right]\left(\mathrm{ClO}_{4}\right)_{2}$, indicating that the water molecule as well as the pendant imidate ester group is involved in coordination. The magnetic moment $\left(2.76 \mu_{\mathrm{B}}\right)$ of $\left[\mathrm{NiL}^{4}\left(\mathrm{H}_{2} \mathrm{O}\right)\right]\left(\mathrm{ClO}_{4}\right)_{2}$ is also consistent with a $d^{8}$ electronic configuration in octahedral coordination geometry. The spectra of $\left[\mathrm{CuL}^{4}\right]\left(\mathrm{ClO}_{4}\right)_{2}$ measured in various solvents also similar to those of $\left[\mathrm{Cu}\left(\mathrm{HL}^{3}\right)\right]\left(\mathrm{ClO}_{4}\right)_{2}$ and other squarepyramidal complexes, ${ }^{15,20}$ indicating that the pendant imidate ester group is coordinated to the metal center. The nickel(II) and copper(II) complexes are quite stable in the solid state and in pure water, acetonitrile, or DMSO.

Solution Behaviors. Both $\left[\mathrm{NiL}^{4}\left(\mathrm{H}_{2} \mathrm{O}\right)\right]^{2+}$ and $\left[\mathrm{CuL}^{4}\right]^{2+}$ readily undergo hydrolysis to give $\left[\mathrm{Ni}\left(\mathrm{HL}^{3}\right)\left(\mathrm{H}_{2} \mathrm{O}\right)\right]^{2+}$ or $\left[\mathrm{Cu}\left(\mathrm{HL}^{3}\right)\right]^{2+}$ in basic aqueous solutions (see above). It has been reported that the $\mathrm{N}-\mathrm{CH}_{2} \mathrm{C}(=\mathrm{NH}) \mathrm{OCH}_{3}$ pendant arms attached to $\left[\mathrm{CuL}^{7}\right]^{2+}$ are readily hydrolyzed to $\mathrm{N}-\mathrm{CH}_{2} \mathrm{COOCH}_{3}$ groups at $\mathrm{pH} \leq 7$, though those attached to $\left[\mathrm{NiL}^{7}\right]^{2+}$ are inert against hydrolysis under similar conditions. ${ }^{23}$ However, $\left[\mathrm{CuL}^{4}\right]^{2+}$ as well as $\left[\mathrm{NiL}^{4}\left(\mathrm{H}_{2} \mathrm{O}\right)\right]^{2+}$ was found to be quite inert against hydrolysis in neutral or acidic aqueous solutions $(1 \leq$ $\mathrm{pH} \leq 7)$; no apparent hydrolysis was observed even after 24 $\mathrm{h}$ at room temperature. The stability of $\left[\mathrm{CuL}^{4}\right]^{2+}$ and $\left[\mathrm{NiL}^{4}-\right.$ $\left.\left(\mathrm{H}_{2} \mathrm{O}\right)\right]^{2+}$ in acidic aqueous solutions was also confirmed by the recrystallization of the complexes from warm $0.1 \mathrm{M}$ $\mathrm{HClO}_{4}$ aqueous solutions.

Electronic absorption spectrum of $\left[\mathrm{Ni}\left(\mathrm{HL}^{3}\right)\left(\mathrm{H}_{2} \mathrm{O}\right)\right]^{2+}$ or

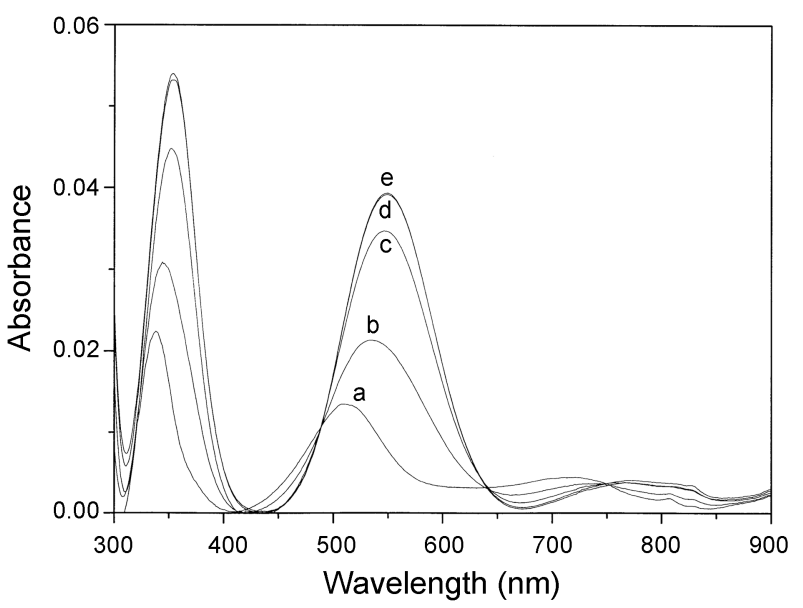

Figure 1. Visible absorption spectra of $\left[\mathrm{Ni}\left(\mathrm{HL}^{3}\right)\left(\mathrm{H}_{2} \mathrm{O}\right)\right]\left(\mathrm{ClO}_{4}\right)_{2}(2.0$ $\left.\times 10^{-3} \mathrm{M}\right)$ measured in $\mathrm{NaOH}$ water-acetonitrile $(1: 1)$ solutions at $25^{\circ} \mathrm{C}$; pH 6.6 (a), 10.4 (b), 11.1 (c), 12.2 (d), and 12.7 (e). The spectra measured in $0.1 \mathrm{M} \mathrm{HClO}_{4}$ and $0.1 \mathrm{M} \mathrm{NaOH}$ solutions are similar to curves a and e, respectively.

$\left[\mathrm{Cu}\left(\mathrm{HL}^{3}\right)\right]^{2+}$ measured in $0.1 \mathrm{M} \mathrm{HClO}_{4}$ solution was found to be nearly the same as that measured in neutral aqueous solution, indicating that the $\mathrm{N}-\mathrm{CH}_{2} \mathrm{CONH}_{2}$ pendant arm is not protonated in the solution. Figure 1 shows that the addition of $\mathrm{NaOH}$ to an aqueous solution of $\left[\mathrm{Ni}\left(\mathrm{HL}^{3}\right)\left(\mathrm{H}_{2} \mathrm{O}\right)\right]^{2+}$ shifts the absorption bands at 337 and $506 \mathrm{~nm}$ to longer wavelengths and increases their molar absorption coefficients. This is attributed to the fact that the complex exists as an equilibrium mixture of $\left[\mathrm{Ni}\left(\mathrm{HL}^{3}\right)\left(\mathrm{H}_{2} \mathrm{O}\right)\right]^{2+}$ and $\left[\mathrm{NiL}^{3}\left(\mathrm{H}_{2} \mathrm{O}\right)\right]^{+}$ (Eq. (1)) in basic aqueous solutions. Figure 1 also shows that the majority part of the complex exists as $\left[\mathrm{Ni}\left(\mathrm{HL}^{3}\right)\left(\mathrm{H}_{2} \mathrm{O}\right)\right]^{2+}$ at $\mathrm{pH} \leq 10$, whereas most of the complex is deprotonated to form $\left[\mathrm{NiL}^{3}\left(\mathrm{H}_{2} \mathrm{O}\right)\right]^{+}$at $\mathrm{pH} \geq 11$. Although the formation of $\left[\mathrm{NiL}^{3}\left(\mathrm{H}_{2} \mathrm{O}\right)\right]^{+}$was confirmed by the isolation of $\left[\mathrm{NiL}^{3}\left(\mathrm{H}_{2} \mathrm{O}\right)\right]-$ $\mathrm{ClO}_{4}$, the deprotonation of the coordinated water could not be excluded in the basic aqueous solutions. The spectra (Fig. 2) of $\left[\mathrm{Cu}\left(\mathrm{HL}^{3}\right)\right]^{2+}$ measured in $\mathrm{NaOH}$ aqueous solutions also

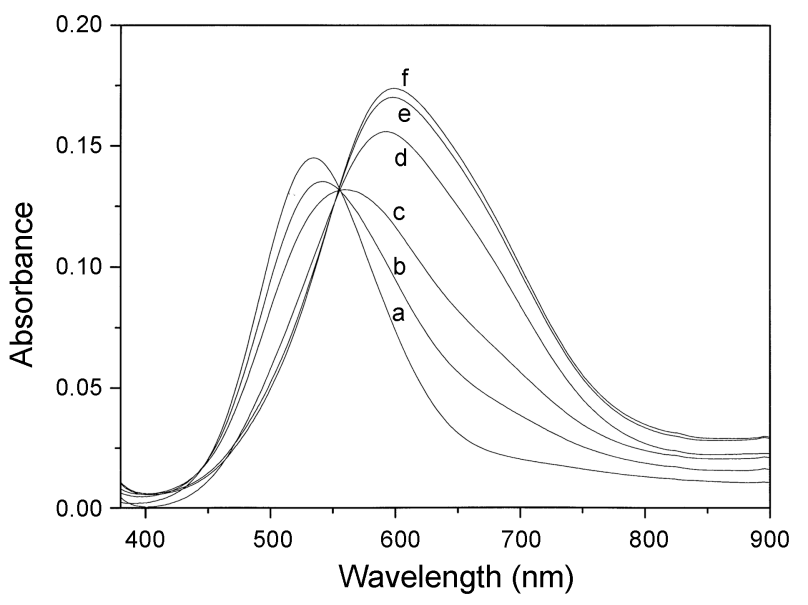

Figure 2. Visible absorption spectra of $\left[\mathrm{Cu}\left(\mathrm{HL}^{3}\right)\right]\left(\mathrm{ClO}_{4}\right)_{2}(1.0 \times$ $10^{-3} \mathrm{M}$ ) measured in $\mathrm{NaOH}$ water-acetonitrile (1:1) solutions at 25 ${ }^{\circ} \mathrm{C}$; pH 7.0 (a), 11.4 (b), 12.0 (c), 12.7 (d), $[\mathrm{NaOH}]=0.05 \mathrm{M}$ (e), and $[\mathrm{NaOH}]=0.1 \mathrm{M}(\mathrm{f})$. The spectrum measured in $0.1 \mathrm{M} \mathrm{HClO}_{4}$ solution is similar to curve a. 
show that the addition of $\mathrm{NaOH}$ shifts the band to a longer wavelength. This also supports the deprotonation of the copper(II) complex and/or the coordination of water (or hydroxide ion) in basic aqueous solutions. In contrast to the case of $\left[\mathrm{Ni}\left(\mathrm{HL}^{3}\right)\left(\mathrm{H}_{2} \mathrm{O}\right)\right]^{2+}$, however, the only copper(II) complex isolated as a solid in the basic aqueous solutions was $\left[\mathrm{Cu}\left(\mathrm{HL}^{3}\right)\right]\left(\mathrm{ClO}_{4}\right)_{2}$.

The approximate $\mathrm{p} K_{\mathrm{a}}$ values of $\left[\mathrm{Ni}\left(\mathrm{HL}^{3}\right)\left(\mathrm{H}_{2} \mathrm{O}\right)\right]^{2+}$ and $\left[\mathrm{Cu}\left(\mathrm{HL}^{3}\right)\right]^{2+}$ were determined at $25^{\circ} \mathrm{C}$ by using a spectrophotometric method. ${ }^{28}$ The $\mathrm{p} K_{\mathrm{a}}$ value $(c a .10 .6)$ for $\left[\mathrm{Ni}\left(\mathrm{HL}^{3}\right)\right.$ $\left.\left(\mathrm{H}_{2} \mathrm{O}\right)\right]^{2+}$ was found to be much smaller than that $(\geq 12.2)$ for $\left[\mathrm{Cu}\left(\mathrm{HL}^{3}\right)\right]^{2+}$. One of the reasons for the easier deprotonation of $\left[\mathrm{Ni}\left(\mathrm{HL}^{3}\right)\left(\mathrm{H}_{2} \mathrm{O}\right)\right]^{2+}$, compared to that of $\left[\mathrm{Cu}\left(\mathrm{HL}^{3}\right)\right]^{2+}$, may be the stronger interaction between the $\mathrm{N}-\mathrm{CH}_{2} \mathrm{CONH}^{-}$ group and the central metal ion of the conjugate base $\left(\left[\mathrm{NiL}^{3}\left(\mathrm{H}_{2} \mathrm{O}\right)\right]^{+}\right){ }^{15}$ In the case of the copper(II) complex, the interaction between the functional group and the metal ion is expected to be relatively weak because of the Jahn-Teller distortion.

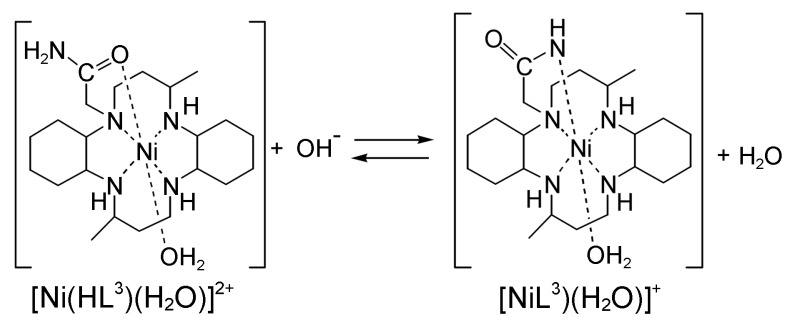

\section{Concluding Remarks}

This work shows that the mono- $N$-cyanomethylated macropolycycle $\mathrm{L}^{11}$, which can be prepared by the reaction of bromoacetonitrile with $\mathrm{L}^{10}$ containing one $\mathrm{N}-\mathrm{CH}_{2}-\mathrm{N}$ linkage, is a useful precursor for the preparation of various types of mono- $N$-functionalized macrocyclic compounds, such as the nickel(II) and copper(II) complexes of $\mathrm{L}^{2}-\mathrm{L}^{4}$. This work also shows that chemical properties of the $\mathrm{N}$ $\mathrm{CH}_{2} \mathrm{CONH}_{2}$ or $\mathrm{N}-\mathrm{CH}_{2} \mathrm{C}(=\mathrm{NH}) \mathrm{OCH}_{3}$ group attached to a macrocyclic complex is strongly influenced by the number of the functional pendant arm and by the nature of the central metal ion.

Acknowledgments. This work was supported by the grant of Daegu University (2010).

\section{References}

1. Viola-Villegas, N.; Doyle, R. P. Coord. Chem. Rev. 2009, 253, 1906.

2. (a) Archibald, S. J. Annu. Rep. Prog. Chem., Sect. A 2010, 106 , 295. (b) Lukes, I.; Kotek, J.; Vojtisek, P.; Hermann, P. Coord. Chem. Rev. 2001, 216, 287.

3. Organo, V. G.; Filatov, A. S.; Quartararo, J. S.; Friedman, Z. M.; Rybak-Akimova, E. V. Inorg. Chem. 2009, 48, 8458.

4. Lacerda, S.; Campello, M. P.; Marques, F.; Gano, L.; Kubiček, V.; Fouskova, P.; Tóth, É.; Santos, I. Dalton Trans. 2009, 4509.

5. Siegfried, L.; Comparone, A.; Neuburger, M.; Kaden, T. A. Dalton Trans. 2005, 30 and references cited therein.

6. Kang, S.-G.; Kim, H.; Kwak, C.-H. Bull. Korean Chem. Soc. 2010, 31, 2701.

7. Martinelli, J.; Balali-Mood, B.; Panizzo, R.; Lythgoe, M. F.; Andrew J. P. White, A. J. P.; Ferretti, P.; Steinke , J. H. G.; Vilar, R. Dalton Trans. 2010, 10056.

8. Costamagna, J.; Ferraudi, G.; Matsuhiro, B.; Vampus-Vallette, M.; Canales, J.; Villagran, M.; Vargas, J.; Aguirre, M. J. Coord. Chem. Rev. 2000, 196, 125.

9. Silversides, J. D.; Allan, C. C.; Archibald, S. J. Dalton Trans. 2007, 971.

10. Kang, S.-G.; Kim, M.-S.; Choi, J.-S.; Whang, D.; Kim, K. J. Chem. Soc. Dalton Trans. 1995, 363.

11. Denat, F.; Diaz-Fernandez, Y. A.; Pallavicini, P.; Pasotti, L. Rousselin, Y. Sok, N. Dalton Trans. 2009, 6751.

12. Siegfried, L.; Kaden, T. A. Dalton Trans. 2005, 3079.

13. Halfen, J. A.; Young, Jr. V. G. Chem. Commun. 2003, 2894.

14. Kang, S.-G.; Kim, S.-J.; Ryu, K.; Kim, J. Inorg. Chim. Acta 1998, 274, 24.

15. Kang, S.-G.; Ryu, K.; Song, J. Polyhedron 1999, 18, 2193.

16. Kang, S.-G.; Kim, N.; Jeong, J. H. Inorg. Chim. Acta 2011, 366, 247.

17. Kang, S.-G.; Song, J.; Jeong, J. H. Bull. Korean Chem. Soc. 2002, 23, 824 .

18. Kaden, T. A. Chimica 2000, 54, 574.

19. Kukushkin, V. Y.; Pombeiro, A. J. L. Inorg. Chim. Acta 2005, 358, 1.

20. Kang, S.-G.; Kim, H.; Kim, N.; Nam, K.; Lee, U. Inorg. Chim. Acta 2010, 363, 1694.

21. Kang, S.-G.; Kim, H.; Kim, N. Jeong, J. H. Bull. Korean Chem. Soc. 2009, 30, 3101.

22. Zhang, Z.; He, Y.; Zhao, Q.; Xu, W.; Li, Y.-Z.; Wang, Z.-L. Inorg. Chem. Commun. 2006, 9, 269.

23. Kang, S.-G.; Nam, K.; Jeong, J. H. Inorg. Chim. Acta 2009, 362, 1083.

24. Kang, S.-G.; Kweon, J. K.; Jeong, G. R.; Lee, U. Bull. Korean Chem. Soc. 2008, 29, 1905.

25. Kang, S.-G.; Kweon, J. K.; Jung, S. K. Bull. Korean Chem. Soc. 1991, 12, 483

26. Wagner, F; Barefield, E. K. Inorg. Chem. 1976, 15, 408.

27. Han, S.; Kim, T.; Lough, A. J.; Kim, J. C. Inorg. Chim. Acta 2011, $370,170$.

28. Sawer, D. T.; Heineman, W. R.; Beebe, J. M. Chemistry Experiments for Instrumental Methods; John Wiley: New York, 1984; pp 193-205. 